\title{
FACTORS CONTROLLING EXOKARST MORPHOLOGY AND SEDIMENT TRANSPORT THROUGH CAVES: COMPARISON OF CARBONATE AND SALT KARST
}

\author{
DEJAVNIKI, KI VPLIVAJO NA KRAŠKO POVRŠINSKO \\ MORFOLOGIJO IN NA PRENOS SEDIMENTOV SKOZI JAME: \\ PRIMERJAVA KARBONATNEGA S SOLNIM KRASOM
}

JIŘÍ BRUTHANS ${ }^{1} \&$ ONDŘEJ ZEMAN ${ }^{1}$

\footnotetext{
${ }^{1}$ Department of Hydrogeology, Engineering Geology and Applied Geophysics, Faculty of Sciences, Charles University, Albertov 6, CZ-128 43 PRAHA 2, CZECH REPUBLIC, e-mail: bruthans@natur.cuni.cz
} 
Jiří Bruthans \& Ondřej Zeman: Factors controlling exokarst morphology and sediment transport through caves: comparison of carbonate and salt karst

In salt karst, very large amounts of sediment load could be permanently trapped underground, due to the high solubility of $\mathrm{NaCl}$. Specific karst forms which have no equivalents in carbonate karst, occur there (huge underground alluvial fans, inlet caves). In a carbonate karst, on the other hand, only small portion of sediment carried by an allochthonous stream could be deposited permanently in the cave, otherwise the cave will become clogged (because of the very low solubility of $\mathrm{CaCO}_{3}$ ). Three carbonate karst areas with long-lasting development and fundamental differences in endokarst and exokarst forms were studied from many different aspects in the Czech Republic. The authors believe that there is only one primary difference between the Moravian Karst and diffuse recharge karst areas (Czech and Chýnov karsts): the frequency and orientation of fissures penetrable by groundwater. All other differences in exokarst and endokarst forms and hydrology are the results of primary difference and its influence on speleogenesis, especially on sediment transport and gradational features. In areas where only bathyphreatic and deep phreatic caves occur, blind valleys and common exokarst morphology never develop, due to the very low velocity of flow in karst conduits, which precludes transport of sediment load.

Key words: exokarst, endokarst, karst evolution, speleogenesis, sediment transport, gradational features, salt karst, Czech Republic, Iran.

\section{Izvleček}

UDK: 551.44(55+437.1)

\section{Jiří Bruthans \& Ondřej Zeman: Dejavniki, ki vplivajo na kraško površinsko morfologijo in na prenos} sedimentov skozi jame: primerjava karbonatnega s solnim krasom

Zaradi velike topnosti $\mathrm{NaCl}$ se v solnem krasu lahko za stalno odlagajo v podzemlju velike količine sedimentov. Tam so posebne kraške oblike, kakršnih ni v karbonatnem krasu: veliki podzemeljski vršaji, notranje jame. Nasprotno pa se v karbonatnem krasu le majhen del sedimentov, ki jih prenaša alohtoni tok, za stalno odloži v jami, saj bi bila sicer jama kmalu zamašena (zaradi zelo slabe topnosti $\mathrm{CaCO}_{3}$ ). Na ozemlju Češke republike so bila z različnih vidikov preučevana tri kraška ozemlja z zelo dolgim razvojem in bistvenimi razlikami med površinskimi in podzemeljskimi oblikami. Avtorja menita, da je le ena bistvena razlika med Moravskim krasom in kraškimi ozemlji z razpršenim napajanjem (Češki in Chýnovski kras): v gostoti in smeri razpok, po katerih prenika kraška voda. Vse ostale razlike v površinskih in podzemeljskih kraških oblikah so nastale zaradi prvotnih razlik in njihovega vpliva na razvoj jam, posebej na prenos sedimentov in na stopnjaste oblike. Na ozemlju, kjer so le batifreatične in globokofreatične jame, se nikoli ne razvijejo slepe doline in druge navadne površinske kraške oblike zaradi zelo počasnega toka v kraških prevodnikih, kar onemogoča prenašanje sedimentov.

Ključne besede: površinski kras, podzemeljski kras, razvoj krasa, speleogeneza, transport sedimentov, stopnjaste oblike, solni kras, Češka republika, Iran. 


\section{INTRODUCTION}

In the Czech Republic, there are many, rather small karst occurrences. They are surrounded by extensive areas of non-karst rocks. The extent of particular areas varied between less than 1 $\mathrm{km}^{2}$ and $140 \mathrm{~km}^{2}$ (Fig. 1).

Long-lasting karstification was documented in a number of areas (Panoš 1964; Bosák 1997). Field evidence proved that small streams have traversed such areas for millions of years (remnants of Tertiary deposits filling valleys, etc.; e.g., Pešek 1972). Hence, there is a sufficient time period for development of underground drainage and consequently expressive superficial karst morphology. Besides areas which really show well-developed exokarst morphology (Moravian Karst), we can also find areas where relatively large caves exist but exokarst morphology and underground streams transporting sediments are completely missing.

Yet only few ideas were published about these phenomena. The areas with a lack of exokarst forms in the Czech Republic are commonly described as 'embryonic karst', which incorrectly indicates that such areas are on the onset of their development (Včíslová 1980). In fact, the absence of exokarst is a permanent property of such areas, irrespective of the time available for karst processes. Bosák et al. (1993) supposed that 'Classical karst did not develop even during the uplift of the Czech Karst and the evolution of an upland type of relief because an old network of corrosion cavities prevented the origin of different drainage paths'. As the modification of older cavities and large changes in drainage path geometry by younger processes are common in karst areas, this explanation seems to be incorrect.

\section{METHODS}

Similarities and differences among several karst areas in the Czech Republic were studied. Velocity of conduit flow was estimated from archive and recently performed tracer tests. The direct distance between injection and sampling points was multiplied by 1.5 to get an estimation of real conduit length (EPA 1999). Mean residence time of karst waters derived from diffuse recharge was studied by tritium and oxygen 18 methods (Žák at al. 2001; Šilar and Záhrubský 1999; Bruthans and Zeman, unpublished). A series of spring and resurgence discharge measurements over a long period collected by the Czech Hydrometeorological Institute were analysed. Longitudinal profiles of caves, transport of sediments via caves and the properties of karst areas were investigated and the results were subsequently compared with sediment transport in salt karst.

\section{EXOKARST FORMS AND SEDIMENT LOAD TRANSPORT THROUGH CAVES IN CARBONATE KARST}

White (1988) described a sediment balance diagram for karst areas. Sediments carried into a cave can be either transported through a resurgence back to the surface, or it can settle in the cave. In carbonate karst only a small portion of sediment carried by allochthonous streams could be deposited permanently in the cave, otherwise the cave will become clogged (due to very low 
solubility of $\mathrm{CaCO}_{3}$ ). This can be simply demonstrated if we compare the volume of blind valleys in non-karst rocks with the volume of related caves which drain such depressions. Commonly the volume of the cave is many times smaller than the volume of the blind valley above the cave.

Development of blind valleys in carbonate karst is therefore restricted to places where almost the whole amount of clastic load carried by streams into sinks is transported via adjacent caves. Evolution of dolines commonly requires underground streams to be able to carry sediment (finegrained fractions). Dolines act as sedimentary traps collecting insoluble residue usually from a much larger areas, than their own surface area. In long-term perspective, relatively large amounts of weathering residue must therefore be transported via the unsaturated zone and consequently via caves to the resurgence to maintain the doline's existence. Collapse dolines have not been considered in this study.

Ford and Ewers (1978) published a classification of phreatic and watertable caves consisting of 4 types:

1) Bathyphreatic cave

2) Multiple loop phreatic cave

3) Mixed phreatic - watertable cave

4) Ideal watertable cave.

These types are used later in the text. For details see Ford and Ewers (1978).

In the ideal watertable cave, where phreatic loops (siphons) are missing, sediment transport of coarse load is analogous to transport in a superficial stream channels. Kranjc (1989) described the auto-regulation of karst conduit cross-section areas by deposition and erosion of sediment. This maintains the velocity of flow sufficient to transport coarse sediment in phreatic loops. In bathyphreatic caves strongly inclined or subvertical portions of phreatic tubes are common. Their inclination exceeds the maximum angle on which sand and silt deposits are stable. In these places the sediments cannot settle and thus reduce the cross-sections of such tube. The cross-section will be further increased with corrosion by a consequent decrease in flow velocity. In such conditions, auto-regulation of conduit cross-section does not work. It is maybe one of the reasons why in bathyphreatic caves the transport of clastic load is either missing (Vaucluse Spring, Christophe Emblanch, personal comm.) or limited to fine fractions only (Sierra de El Abra in Mexiko, Ford in Klimchouk et al. 2000).

\section{SEDIMENT TRANSPORT THROUGH CAVES AS SPELEOGENETIC AGENT}

Sediments play a key role in gradational features such as paragenesis, bypassing and vadose entrenchments. Paragenesis is caused by an insoluble suspended load, which protects the bed and lower walls, prohibiting solution there (Ford and Ewers 1978). Bypassing is caused by temporary extreme increases of hydraulic gradient across the phreatic loop due to trapping of sediments in the downward parts of these loops and consequent reduction of the cross-section of the conduit (Ford and Ewers 1978). Where sediment transport does not take place, these gradational features cannot occur.

Another important feature typical of karst conduits, where transport of clastic load is absent, is low discharge variation. This is caused by a recharge mode which is rather diffused. Only a minor part of the water can pass underground during floods. The predominant part continues on 
its superficial way. This further inhibits the possibility of bypassing taking place due to low discharge variation in the conduit. Diffused recharge through the stream riverbed can cause the origin of maze pattern of caves in areas traversed by allochthonous streams (c. $f$. Palmer 1991).

\section{SELECTED KARST AREAS IN THE CZECH REPUBLIC}

In the Czech Republic a great variety of karst areas exist (Fig. 1). Two end members with respect to the presence of exokarst forms and sediment transport via caves were selected:

1) Moravian Karst representing areas with a well-developed exokarst forms and the existence of large underground streams transporting coarse clastic loads.

2) Czech Karst and Chýnov Karst, further in the text called diffuse recharge karst areas

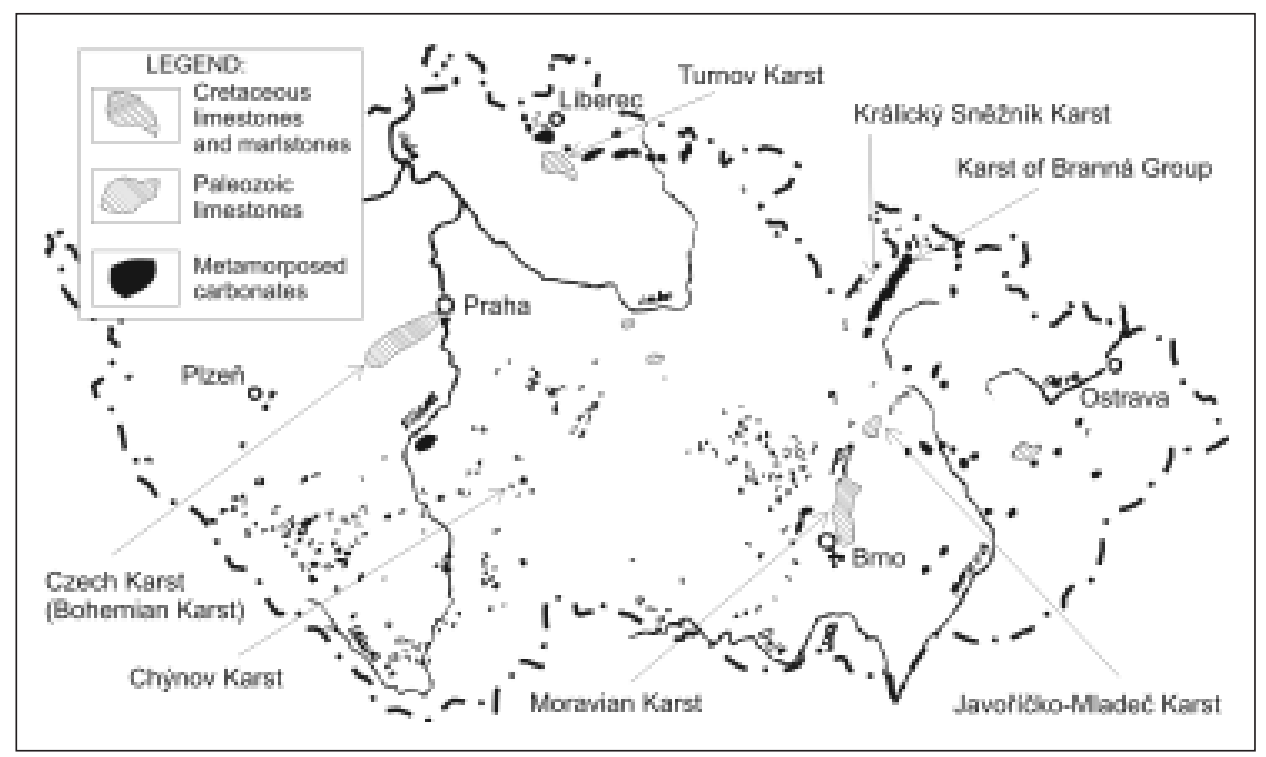

Fig. 1: Karst areas in the Czech Republic. Modified after Pribyl et al. (1992).

\section{Moravian Karst}

Moravian karst is situated about $20 \mathrm{~km}$ north of the town of Brno. It is the second largest (area about $80 \mathrm{~km}^{2}$ ) and best-developed karst area in the Czech Republic composed of Devonian and Lower Carboniferous limestones. Blind valleys, half-blind valleys, karst canyons, dolines, underground streams, ponors and resurgences are common. More than 1000 caves with a total length exceeding $80 \mathrm{~km}$ are known here (Hromas and Bílková 1998). Evolution of the largest caves (Amatérská Cave, Rudické propadání - Býčí skála Cave) started in the Miocene and was interrupted by the Badenian marine transgression (Panoš 1963; Kadlec et al. 2001). 
One typical feature could be traced in the Moravian Karst. Young cave passages represent a mixture of phreatic and watertable components, e.g. the phreatic part of Piková Dáma-Spirálka Cave and Štaigrova díra Cave (Fig. 2). On the other hand, cave passages showing long-lasting
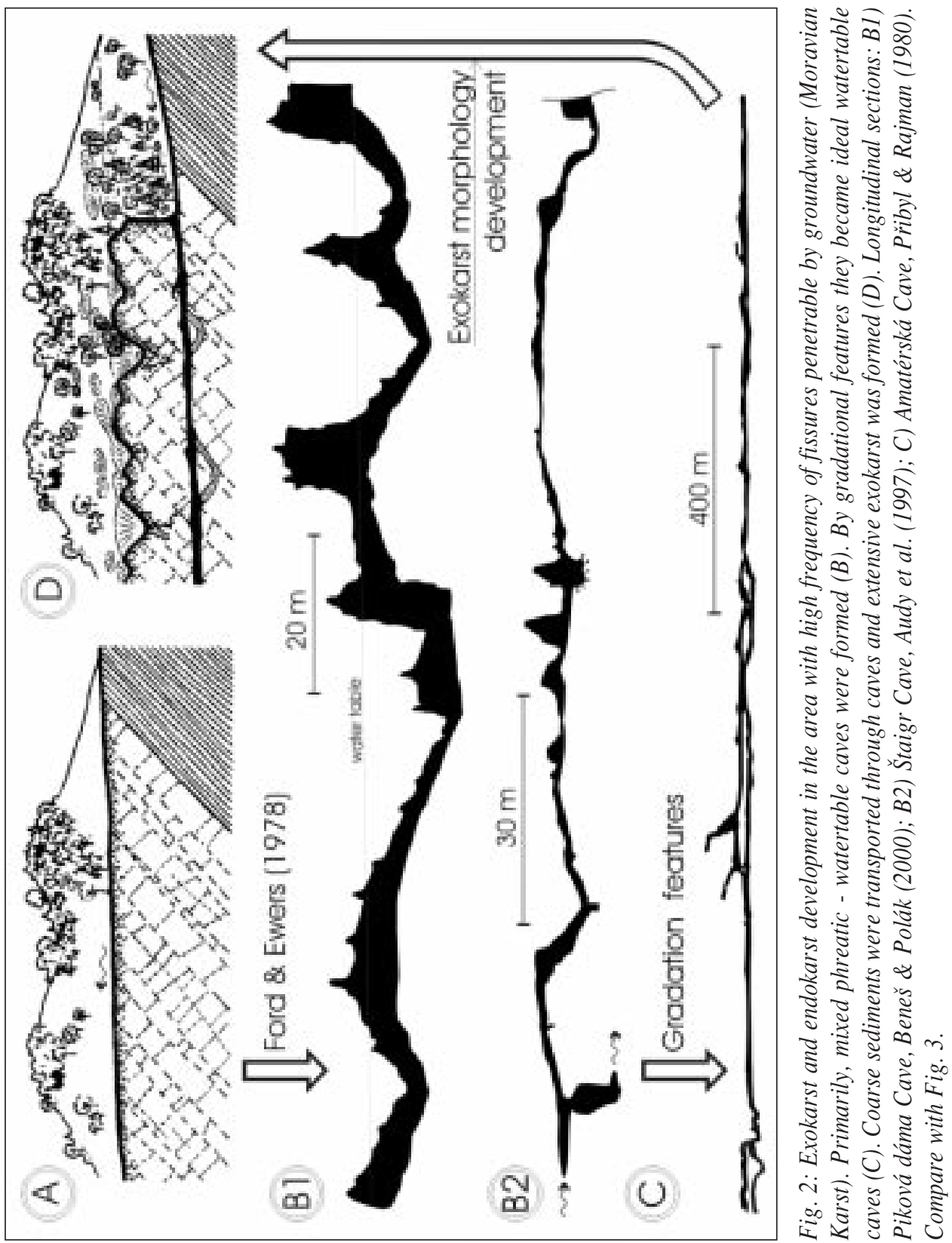


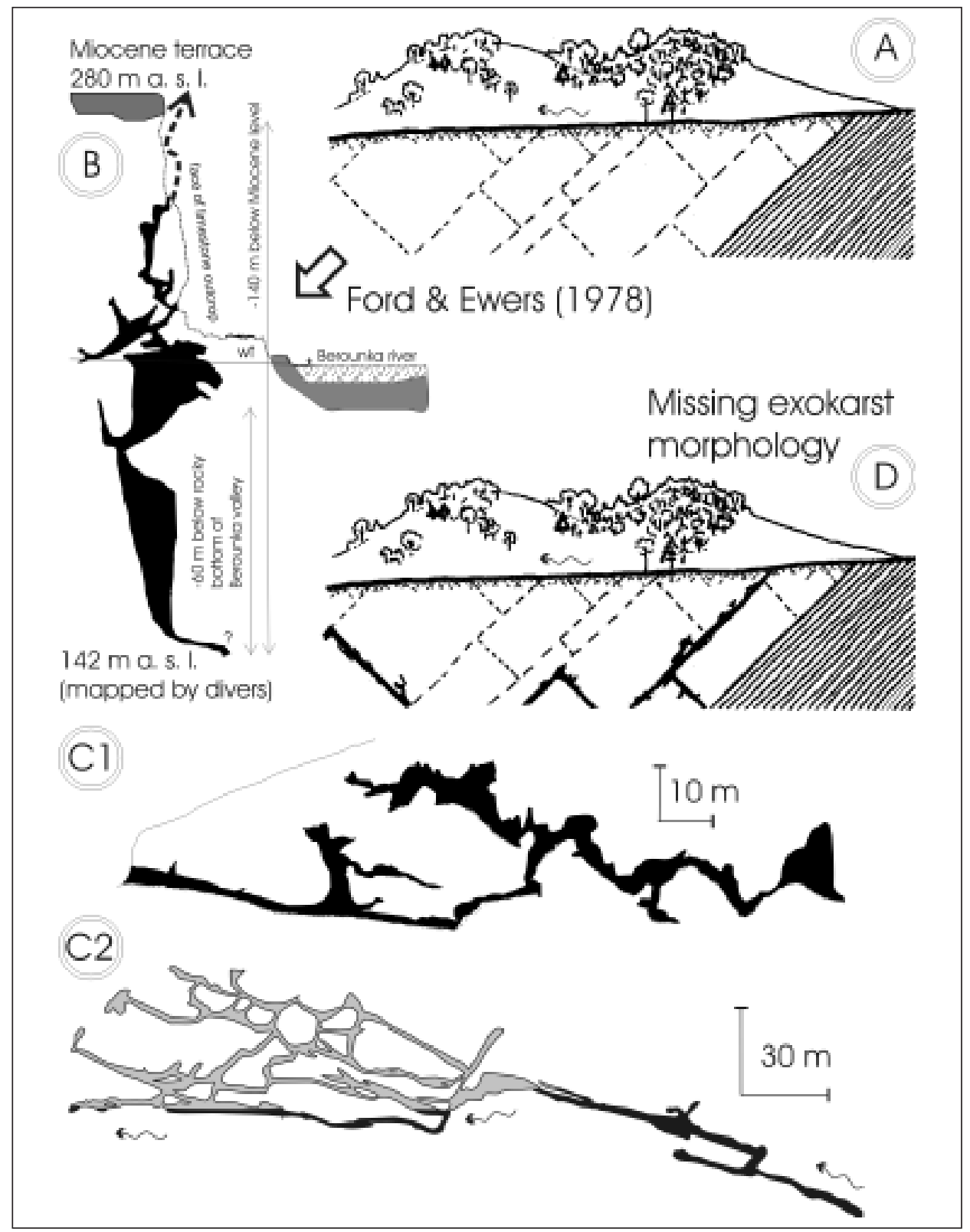

Fig. 3: In the area with low frequency of fissures penetrable by groundwater and rather low hydraulic gradient (Czech and Chýnov karsts) lack of exokarst morphology is permanent property $(A$ and $D)$. Bathyphreatic $(B)$ and multiple loop phreatic caves $(C)$ occur. Longitudinal sections: B) Podtratová Cave, modified after Zapletal (1989); C1) Nad Kačákem Cave, Vlk et al. (2001); C2) Chýnovská Cave, Krejča et al. (2001). For better depiction, epikarst zone is omitted. 
development are almost ideal watertable caves (upper level of Amatérská Cave; Rudické propadání - Býčí Skála Cave; Ochoz Cave).

\section{Czech Karst (Bohemian Karst)}

The Czech Karst is the largest karst region in the Czech Republic with a total area of $140 \mathrm{~km}^{2}$. It is located in the surroundings of Prague (Fig. 1). The rock sequence (with Silurian to Middle Devonian limestones) was folded during the Variscan Orogeny. The predominant part of caves is developed in 120 up to 300 m thick regional aquifer belonging mainly to high-grade Devonian limestones (Bruthans and Zeman 2001). The regional aquifer is partly confined by sandstone and shale, and impure limestone. In synclines, the regional aquifer is buried as much as $600 \mathrm{~m}$ below the ground surface. More than 550 caves with a total length of nearly $20 \mathrm{~km}$ were developed there (Karel Žák, personal comm.). The recent period of cave evolution started already in the Oligocene - Miocene period, based on palaeontological evidence (c.f. Bosák et al. 1989).

The Czech Karst differs considerably from common karst regions. Sinks of surface streams, streamed caves, dolines and other common karst features are generally missing here. Instead, three-dimensional maze caves, phreatic in origin, with highly irregular cross-sections occur in the Czech Karst (c.f. Bosák et al. 1993; Fig. 3). With very few exceptions, springs are never turbid in the area.

There are no traces of sinking stream activity from the past. Cave sediments show transportation by episodic inflows via unsaturated zone and soil creep. Sedimentary evidence of fast flow was found only in the close vicinity of the Berounka River; gravel and sand have been transported by river flood injection there.

Multiple loop phreatic caves prevail in the area (Nad Kačákem Cave, Barrande Cave -Fig. 4). There are also several bathyphreatic caves (Podtratová Cave, Arnoldka Cave - Fig. 5). The known depth of loops in bathyphreatic caves exceeds $100 \mathrm{~m}$; continuation being either closed by clay or situated too deep under the watertable to be investigated by diving (Podtratová Cave, Fig. 3). In the area of Czech Karst there are two springs with temperature 3.5 and $4{ }^{\circ} \mathrm{C}$ higher than the mean air temperature on the surface (Svatý Jan Spring, Bublák Spring) as well as many other springs with slightly lower temperatures. Depth of groundwater circulation was computed by means of formulas which take into account the partial consumption of Earth heat flow due to warming of the circulating water (Bruthans in Žák et al. 2001). The computed depth of groundwater flow is up to $600 \mathrm{~m}$ below ground surface. This is fairly high depth if we consider that the difference in landscape altitude between recharge and discharge areas is only 60 - $200 \mathrm{~m}$. Water must descend several hundred meters below the base level. The real depth of phreatic loops can therefore be several hundred meters in places.

On the other hand, there are neither recent nor ancient examples of ideal watertable caves or mixed phreatic - watertable caves in the Czech Karst.

\section{Chýnov Karst}

Chýnov Cave with a length of about $1400 \mathrm{~m}$ is located in a small $\left(1 \mathrm{~km}^{2}\right)$ metamorphosed carbonate occurrence in southern Bohemia near the town of Tábor (Hromas and Bílková 1998). Two small superficial streams cross the carbonate strip close to the cave. The existence of Chýnov Cave and the above-mentioned streams could be dated back at least to the Miocene (Badenian), since Mydlovary Formation deposits were found in the Chotčický Brook valley bottom, the water 


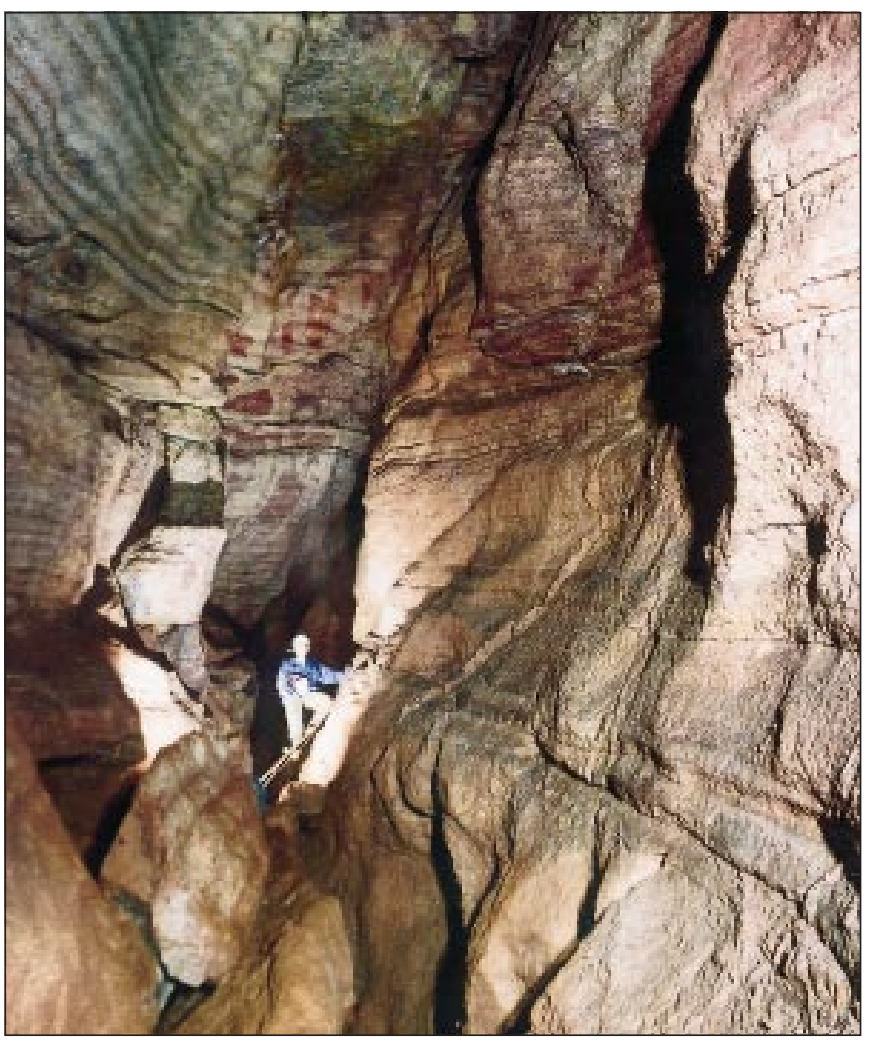

Fig. 4: Steeply inclined bathyphreatic passage (Arnoldka Cave, Czech Karst).

Fig. 5: Barrande Cave, example of multiple loop phreatic cave.

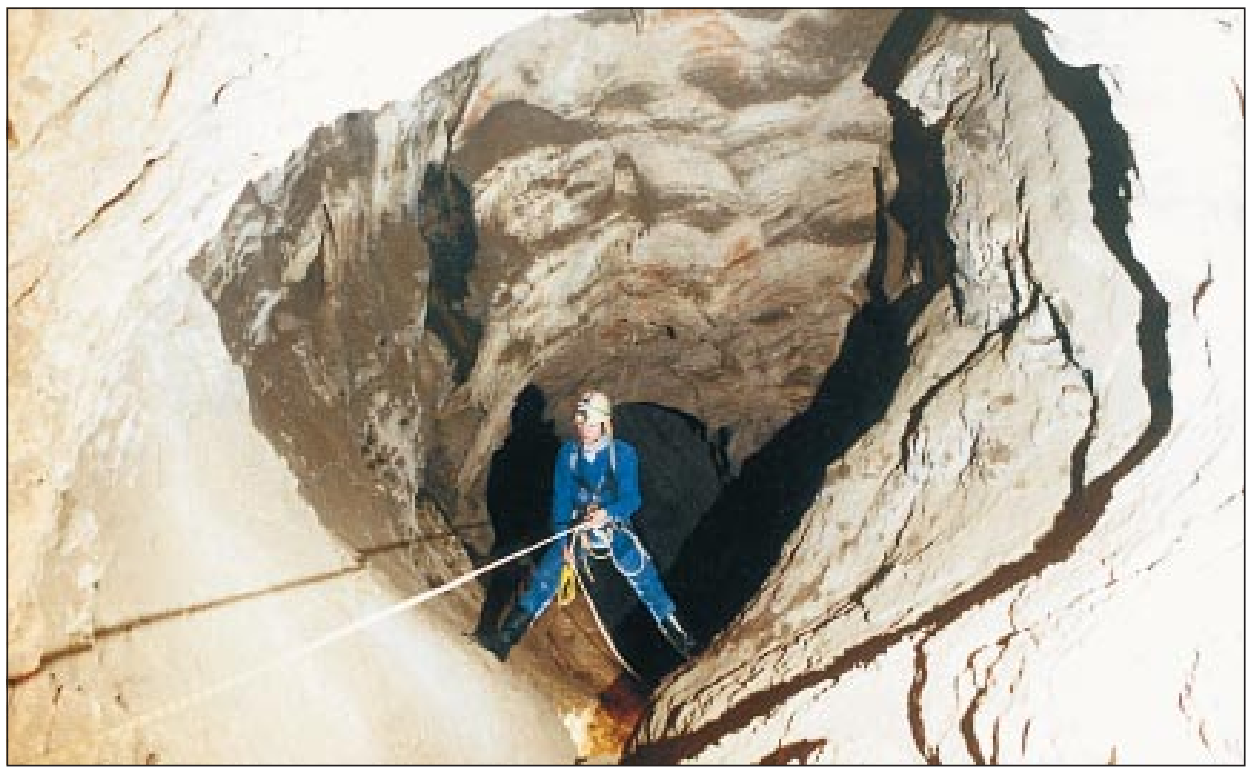




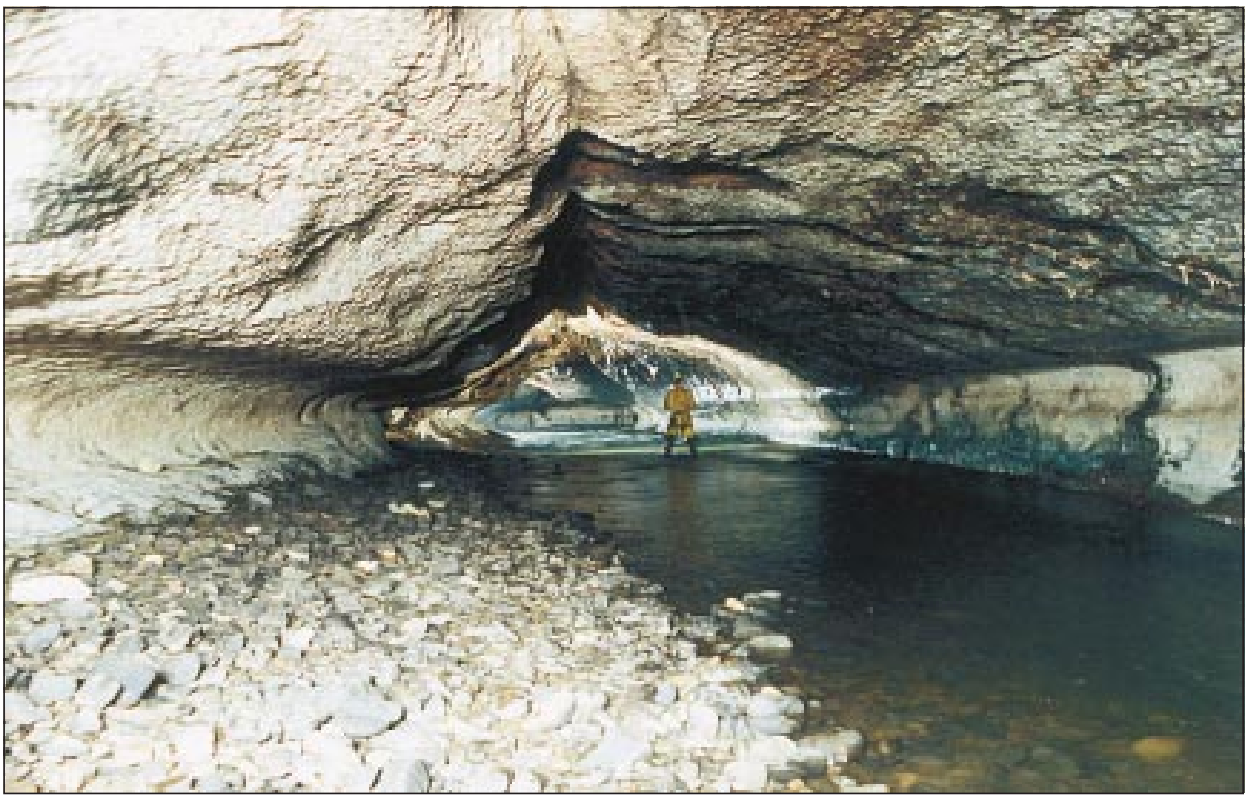

Fig. 6: Amatérská Cave, Singleness passage. Ideal watertable cave covered by coarse gravel fill.

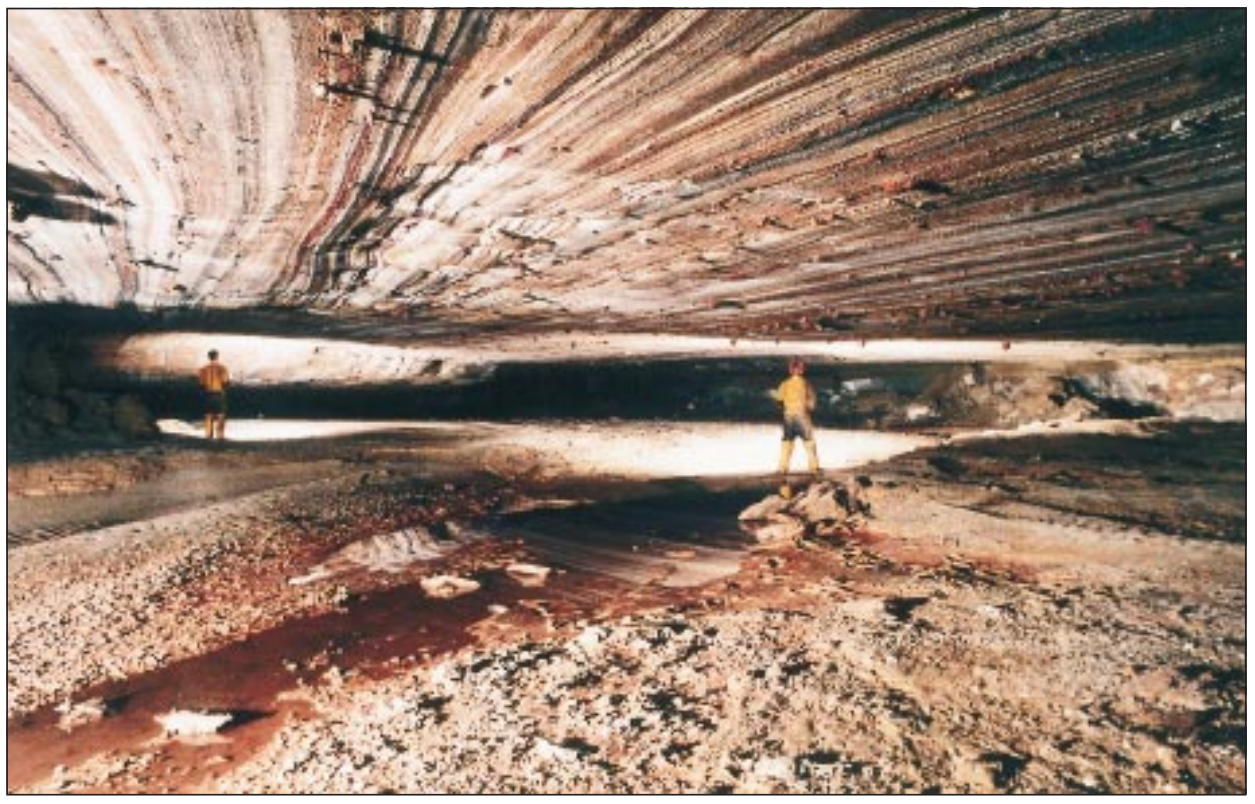

Fig. 7: Tř́ Naháčủ Cave, Namakdan highway corridor, Iranian salt karst. Extremely broad but low passage is the result of underground stream meandering. Only fine fractions are transported through cave, as cobbles and gravel is deposited on huge underground alluvial fan on the onset of cave. 
supply for more than 70 years. No accumulation of clastic load was found in the water supply reservoir. Mean velocity of flow between Chýnov Cave and Rutice Spring is $1.8 \mathrm{~cm} . \mathrm{s}^{-1}$ based on tracer test (Skřivánek 1962). After extreme precipitation events in August 2002, which led to catastrophic floods in the Czech Republic the yield of the cave stream rose only twice compared to minimum value (František Krejča, personal comm.). Flow velocity in feeding siphon was still less than $1 \mathrm{~mm} \cdot \mathrm{s}^{-1}$ based on yield measurement and siphon cross-section!

\section{COMPARISON OF KARST AREAS PROPERTIES}

Properties which are equivalent or similar for all areas (Moravian, Czech and Chýnov Karst):

1) Long-lasting karstification and existence of small superficial streams draining the surrounding nonkarst areas (millions of years).

2) Long-lasting intermediate gradient between recharge and discharge areas (differences in altitude between 50 and $300 \mathrm{~m}$ to distance of several kilometres).

3) Well developed endokarst. Total length of cave passages: Moravian Karst $80 \mathrm{~km}$; Czech Karst 20 km; Chýnov Karst 1.4 km.

The above-mentioned properties are proof that in all areas suitable allochthonous streams exist and time and hydraulic gradient are sufficient for development of underground streams and consequently exokarst morphology (c.f. Palmer 1991). Some factors precluding clastic load transport via caves must therefore exist in diffuse recharge areas.

4) Mean residence time of autochthonous waters is between several years up to several decades, based on oxygen 18 and tritium dating in all areas (Žák et al. 2001; Bruthans, unpublished).

5) Extent of autochthonous catchments (up to $10 \mathrm{~km}^{2}$ ) based on mean yield of springs and groundwater runoff.

6) Flow velocity in conduits at normal conditions. During dry periods velocities are similar between conduits in the Moravian Karst (between 0.1 and $22 \mathrm{~cm} \cdot \mathrm{s}^{-1}$ ) and Chýnov and Czech karsts $\left(0.9\right.$ and $\left.2.1 \mathrm{~cm}^{-1}\right)$, based on results of tracer tests. Unfortunately, only a few tracer tests were carried out in diffuse recharge areas. On the other hand, flow velocities during flood events differ significantly.

7) Similar size of clastic load transported in streams from non-karst areas.

Properties, which differ significantly between two end members of areas:

1) Longitudinal profile of caves (recent and old). Watertable caves prevail in Moravian Karst and Turnov Karst, where blind valleys only developed in the Czech Republic. On the contrary, only deep phreatic caves and bathyphreatic caves are present in Czech and Chýnov karsts.

2) Fissure frequency and orientation. The longitudinal profile of caves is a function of the frequency of fissures penetrable by groundwater (Ford and Ewers 1978). Hence, in Moravian karst, fissure frequency is high. In Czech and Chýnov Karst, it is low. Unlike other areas, subhorizontal fissures are commonly guiding cave passages in Moravian Karst.

3) Presence of exokarst. Existence of well-developed exokarst in Moravian Karst (dolines, large blind valleys, etc.). In the Czech and Chýnov karsts, exokarst forms are almost missing.

4) Sediment transport through caves. Streams transporting coarse sediments via caves are com- 
mon in the Moravian Karst. In the Czech and Chýnov karsts, there is even no turbidity of spring water during heavy rains (with very few exceptions).

5) Recharge pattern. In Moravian Karst autochthonous streams are sinking in concentrated ponors with large capacities (up to $180001 . \mathrm{s}^{-1}$ ). In Czech and Chýnov karsts, there are no concentrated losses of water into riverbeds at all. At a few places, water is diffusively passing through sediments into underlying limestone.

6) Permeability of underground routes. The largest conduits in Moravian Karst can transmit up to $460001 . \mathrm{s}^{-1}$ during floods (Punkva Resurgence). In contrast, in Chýnov and Czech karsts the maximum discharge of springs is less than $401 . \mathrm{s}^{-1}$.

7) Spring discharge variation. The ratio of the highest and the lowest discharge of resurgence is commonly several hundred up to 1100 in the Moravian Karst (Punkva, Jedovnický potok Resurgence). In Czech and Chýnov karsts it is always less than 70 and usually less than 10; based on long-term discharge measurements.

8) Maximal flow velocity in conduits. During floods, velocity of flow can reach several meters per second in some conduits in the Moravian Karst (over the whole length of the cave). Thus it may transport coarse gravel ( $>30 \mathrm{~cm}$ in size) through caves (Fig. 6). In Czech and Chýnov karsts, the rise of velocity in conduits during largest precipitation events is very low and irregular, to be capable of transporting even fine fractions. Flow velocities in some parts of siphons never exceed $1 \mathrm{~mm} . \mathrm{s}^{-1}$ in diffuse recharge karsts (low maximum discharge, large cross-sections).

9) Allochthonous water predominates in resurgences in the Moravian karst. Springs are supplied by autochthonous water nearly exclusively in diffuse recharge karsts.

\section{DISCUSSION}

We assumed that there is only one primary difference between Moravian Karst and diffuse recharge karst areas - the frequency and orientation of fissures penetrable by groundwater.

In the Moravian Karst high fissure frequency and existence of subhorizontal fissures enabled development of mixed phreatic-watertable caves. Transport of silt and sand via caves began. By long-lasting bypassing and paragenesis, which removed the predominant part of phreatic loops, the caves became watertable caves (Fig. 2). In such conditions, transport of all fractions of clastic load carried by streams was enabled through underground routes. As a consequence, blind valleys and large dolines developed. Large and relatively uniform cross-section of karst passages enables transmission of huge amounts of water from floods. Amatérská Cave, Rudické propadání - Býčí Skála Cave and Ochoz Cave are examples.

There are other caves in the Moravian Karst where phreatic loops were removed probably to a lesser degree. Transport of the coarsest fractions of sediments is not possible via such caves (Křtinský potok Ponor - Resurgence, Řiccka Ponor - Resurgence, Propadání Lopače Cave - Stovka Cave). Hence, blind valleys are lacking in catchments of these later mentioned caves.

In diffuse recharge areas (Czech Karst, Chýnov Karst), low fissure frequency prevents development of mixed phreatic - watertable caves. Bathyphreatic caves and multiple loop phreatic caves were developed instead (Fig. 3). The velocity in conduits was not sufficient to transport sediment via caves (very deep and complicated phreatic loops and relatively low hydraulic gradi- 
ent between recharge and discharge areas). Hence, gradational features cannot remove phreatic loops and the longitudinal profiles of caves remained unchanged until recent time. The development of blind valleys and exokarst morphology was precluded, since even the finest fractions of sediments (weathering residuum) cannot be washed from caves back to the surface. Spring yields are low as consequence of relatively small autochthonous catchment areas and low groundwater runoff (up to $31 . \mathrm{s}^{-1} \cdot \mathrm{km}^{-2}$ ). Variation in spring discharge remained low due to lack of open recharge paths (ponors, dolines).

Sediment transport through caves could be precluded also in areas where fissure frequency is high but the geological setting prevents shallow phreatic cave development along whole paths among recharge and discharge areas (carbonates sunken into great depths between the recharge and discharge area due to tectonic movements, etc.).

Nice examples are provided by the Javoříčko - Mladeč Karst, the area with very similar geology as the Moravian Karst. Sediment transport takes place in caves developed in limestone outcrop areas. Recent examples are Kovářov ponor - resurgence and Ponikve ponor- Andělička Resurgence. Javoříčko Cave is an abandoned watertable cave filled by coarse gravels. On the other hand, there is a karst conduit developed between Špraněk Creek ponor - Rimice Springs. Limestones were buried to considerable depth below non-karst rocks between recharge and discharge areas. Sediment transport does not take place in this conduit (no turbidity of spring water).

In mountain areas in the Czech Republic, where mixed phreatic - watertable caves exist (Králický Sněžník Karst, Karst of Branná Group; Table 1) the development of blind valleys is not possible due to coarse cobbles $(0.2-0.6 \mathrm{~m})$ transported by sinking streams. Dolines are common inplaces (Karst of Branná Group).

Table 1: Examples of caves in the Czech Republic whose longitudinal profiles were classified in this study. Amatérská Cave profile was already studied by Kadlecová \& Kadlec (1995).

\begin{tabular}{|c|c|c|c|}
\hline Karst area & Cave & $\begin{array}{c}\text { State (Ford and } \\
\text { Ewers, 1978) }\end{array}$ & Fig. No. \\
\hline \multirow[t]{5}{*}{ Moravian Karst } & Piková dáma-Spirálka (part) & 3 & $2 \mathrm{~B} 1$ \\
\hline & Štaigr Cave & 3 & $2 \mathrm{~B} 2$ \\
\hline & Amatérská Cave (upper level) & 4 & $2 \mathrm{C}$ \\
\hline & Rudické Propadání-Býčí Skála & 4 & \\
\hline & Ochoz Cave & 4 & \\
\hline Turnov Karst & Bartošova pec Cave & 4 & \\
\hline Javoříčko-Mladeč Karst & Javoříčko Cave & 4 & \\
\hline \multirow[t]{3}{*}{ Czech Karst } & Podtratová Cave & 1 & $3 \mathrm{~B}$ \\
\hline & Arnoldka Cave & 1 & \\
\hline & Nad Kačákem Cave & 2 & $3 \mathrm{C} 1$ \\
\hline Chýnov Karst & Chýnov Cave & 2 & $3 \mathrm{C} 2$ \\
\hline Králický Sněžník Karst & Tvarožné díry Cave & 3 & \\
\hline Branná Group Karst & U Borovice, Za hájovnou Cave & 3 & \\
\hline
\end{tabular}




\section{SEDIMENT TRANSPORT THROUGH CAVES IN SALT KARST}

Unlike carbonate karst, the extreme solubility of $\mathrm{NaCl}\left(360 \mathrm{~g} . \mathrm{l}^{-1}\right)$ enables the corrosion enlargement of salt caves to keep pace with large amounts of sediment carried into caves by allochthonous streams. The predominant portion of sediments can be trapped in karst environment. Specific karst forms which have no equivalent in carbonate karst occur there: Frumkin (1994) described 'Inlet caves', e.g. caves with no distinct outlet on Mt. Sedom salt plug in Israel. Clastic load carried into caves by sinking intermittent streams is deposited in the inlet caves. Space occupied by sediment fill is compensated by corrosion of salt walls. In the upper part of Tří naháčů Cave (Queshm Island, Iran) an extensive underground alluvial fan was found (Bruthans et al. 2000, Fig. 2). Coarse-grained sediment fractions carried by two large intermittent streams into the cave (several centimetres up to $1 \mathrm{~m}$ in size) are deposited on this fan. Only sand is transported through the lower part of the cave (Fig. 7). On the Mt. Sedom salt plug, phreatic loops in caves are completely lacking (Frumkin 1994). There are only two known phreatic loops in Iranian salt karst (Cave H3; Bosák et al 1999). Existence of phreatic loops is possible thanks to the entrapment of large amounts of insoluble residue directly below dolines, which is common feature of thin cap rock environment (Bruthans et al. 2000).

\section{CONCLUSIONS}

In salt karst very large amounts of sediment could be permanently trapped in the underground due to the high solubility of the host rock. Specific karst forms, which have no equivalent in carbonate karst, occur there (huge underground alluvial fans, inlet caves). In carbonate karst, on the other hand, only a small portion of sediment carried by allochthonous stream can be deposited within the cave, otherwise the cave would be clogged up due to comparatively low solubility of $\mathrm{CaCO}_{3}$.

A common karst landscape with blind valleys and frequent dolines could be developed in carbonate karst only if:

1) Time period available for karstification is sufficiently long.

2) Gradient among recharge and discharge areas is high enough to enable transport of the sediment load carried into the area by allochthonous streams.

3) There are no circumstances in geological settings which prevent a shallow phreatic cave developing along the whole length among recharge and discharge areas (e.g., carbonates sunken to great depths between the recharge and discharge areas due to tectonics movements, etc.)

4) The frequency of fissures penetrable by groundwater is sufficiently high to enable ideal watertable caves or mixed phreatic-watertable caves to develop.

In areas where only bathyphreatic and deep phreatic caves occur, blind valleys and common exokarst morphology will never develop, due to very low velocity of flow in karst conduits, which precludes sediment load being transported through caves. The absence of exokarst is a typical and permanent property of such areas, irrespective of time available for karst processes to occur. 
The frequency of fissures penetrable by groundwater, which controls the longitudinal profile of caves (Ford and Ewers 1978), acts as a very important divide for further exokarst and endokarst development:

1) In the cave that permits clastic load transport, the gradational features could markedly increase the length of watertable components. Finally, transport of course gravel via caves starts and pronounced exokarst developed.

2) Caves that do not permit sediment transport remain unchanged in longitudinal profile as the gradational features cut down. Exokarst is lacking in general.

Relatively small initial differences in fissure frequency between two areas can finally result in extremely different appearances of exo- and endokarst morphology and hydrology of such areas. The above rules are demonstrated in differences among karst areas in the Czech Republic. The authors believe, that there is only one primary difference between Moravian Karst and diffuse recharge karst areas (Czech and Chýnov karsts) - the frequency and orientation of fissures penetrable by groundwater. All other differences in exokarst and endokarst forms and hydrology are results of primary difference and its influence on speleogenesis, especially on sediment transport and gradational features.

There are some important limitations for conclusion generalisations of this study to other carbonate karst areas resulting from the following circumstances: Only relatively small karst occurrences in one country were studied. The hydraulic gradient in any particular area was rather low. In areas where extreme hydraulic gradients occur, at least during flood events, the extreme velocities enable transport of course gravel even through multiple loop phreatic caves (Castleguard Cave - Ford in Klimchouk et al. 2000).

One should be aware that areas with lacking exokarst are much less sensitive to pollution compared to areas depicting expressive exokarst morphology. The mean velocity of flow in conduits in diffuse recharge karst areas is still several orders of magnitude higher than velocity in porous and fissured rocks. The vulnerability of any karst area should be tested by tracer tests and other methods studying the water flow, to be not only based on degree of exokarst development.

\section{ACKNOWLEDGEMENTS}

This study was carried out with the financial support of the Grant Agency of the Ministry of Education project no. FRVŠ 2001/2066 and the Grant Agency of Charles University project no. GAUK 2001/197. The Czech Hydrometeorological Institute provided a series of spring and resurgence discharge measurements, which were analysed in this paper. Special thanks to Pavel Bosák and Karel Žák for valuable comments and Kevin Brett who kindly improved the English of manuscript. Many thanks to Ondřej Jégr and Helena Vysoká for assistance on tracer tests and other field works. 


\section{REFERENCES}

Audy, I. \& M. Audy \& B. Vitouchová, 1997: Atlas jeskynní Moravského krasu díl 1, Pustý žleb, p. 1-328, Blansko

Beneš, L. \& Polák, P., 2000: Jeskynní systém Piková dáma - Spirálka. - Estavela 5:22. Brno.

Bosák, P., 1997: Paleokarst of the Bohemian Massif in the Czech Republic: an overwiev and synthesis. - International Journal of Speleology, 24, 1995, 1-2, p. 3-40, L'Aquila

Bosák, P. \& I. Horáček, 1989: Paleokarst. A systematic and regional review. - Academia, p. 1-719, Praha

Bosák, P. \& V. Cílek \& J. Bednářová, 1993: Tertiary morfogeny and karstogenesis of the Bohemian karst. - Knih. Čes. speleol. spol., 21 (Krasové sedimenty): p. 10-19, Praha

Bosák, P. \& J. Bruthans \& M. Filippi \& T. Svoboda \& J. Šmíd, 1999: Karst and Caves in the Salt Diapirs, SE Zagros Mts., Iran. - Acta Carsologica, 28, 2, p. 41-75, Ljubljana

Bruthans, J. \& J. Šmíd \& M. Filippi \& O. Zeman, 2000: Thickness of caprock and other important factors affecting morphogenesis of salt karst. - Acta Carsologica, 29, 2, p. 51-64, Ljubljana

Bruthans, J. \& O. Zeman, 2001: Hydrogeological investigation of the Bohemian Karst, methodology and results. $-7^{\text {th }}$ Conference on Limestone and Fissured Media, p. 77-80, Besancon (France)

EPA, 1999: The QTRACER program for Tracer Breakthrough Curve Analysis for Karst and Fractured-rock karst aquifers. - U.S. Environmental protection agency hypertext multimedia publication in the Internet at http://www.epa.gov/NCEA/pdfs/qtracer/qtracer.pdf

Ford, D.C. \& R.O. Ewers, 1978: The development of limestone cave systems in the dimensions of lenght and depth. - Can. J. Earth Sci., 15, p. 1783-1798

Frumkin, A., 1994: Morphology and development of salt caves. - Natl. Speleol. Soc. Bull., 56, p. 82-95, Huntsville.

Hromas, J \& D. Bílková, 1998: Caves and karst areas of the Czech Republic. - Agentura ochrany a krajiny České republiky. Kartografie, Praha

Kadlec, J. \& H. Hercman \& V. Beneš \& P. Šroubek \& J. Diehl \& D. Granger, 2001: Cenozoic history of the Moravian Karst (Northern segment): Cave sediments and Karst morphology. - Acta Mus. Moraviae, Sci. geol., 89, p. 111-160, Brno

Kadlecová, R. \& J. Kadlec, 1995: Vznik a stáří Amatérské jeskyně. - Speleo, 20, p. 16-22, Praha

Klimchouk, A.B. \& D.C. Ford \& A.N. Palmer \& W. Dreybrodt, 2000: Speleogenesis, Evolution of Karst Aquifers. - NSS, p. 1-521, Huntsville, USA

Kranjc, A., 1989: Recent fluvial cave sediment and their origin and role in speleogenesis, p. 115, SAZU, Ljubljana.

Krejča, F. \& J. Vandělík \& K. Drbal, 2001: Chýnovská jeskyně.-Agentura ochrany přírody a krajiny České republiky, Správa Chýnovské jeskyně, Brno

Palmer, A.N., 1991: Origin and morfology of limestone caves. - Geol. Soc. Amer. Bull., 103, p. 1-21

Panoš, V., 1963: K otázce původu a stáří sečných povrchů v Moravském krasu. - Čs. kras, 14, p. 29-41, Praha.

Panoš, V., 1964: Der Urkarst in Ostflügel der Böhmishen Masse. - Zeitschrift für Geomorphologie, N.F., 8, 2, p. 105-162 
Pešek, J., 1972: Terciérní sedimenty ve středních a západních Čechách. - Sbor. Západočes. muz. v Plzni, Př́r., 6, p. 1-55, Plzeň.

Přibyl, J. \& P. Rajman, 1980: Punkva a její jeskynní systém v Amatérské jeskyni. - Studia Geographica, 68, p. 1-141

Přibyl, J. \& V. Panoš \& V. Ložek \& B. Kučera \& P. Bosák \& V. Cílek \& A. Jančařík \& K. Sklenář \& J. Vašátko \& K. Kirchner \& J. Slačík \& V. Šmejkal \& O. Štěrba \& V. Vlček, 1992: Základy karsologie a speleologie - Academia, ČSAV, p. 1-354, Praha

Skřivánek, F., 1962: K stoletému výročí objevu Chýnovské jeskyně u Tábora. Československý kras, 15, ČSAV, Praha.

Šilar, J. \& K. Zahrubský, 1999: Concetración inicial de radiocarbono en aguas subterráneas del Karst de Bohemia Central. - In Andreo, B. \& F. Carrasco \& J.J. Durán (Eds.), Contribución del estudio científico de las cavidades kársticas al conocimiento geológico., Cueva de Nerja, Nerja (Málaga)

Včíslová, B., 1980: Silur - devon Barrandienu - II. fáze - závěrečná zpráva. MS Stavební geologie, p. 1-191, Praha.

Vlk, L. \& J. Novotná \& M. Novotný, 2001: The Nad Kačákem Cave again longer (in Czech).Speleofórum 2001, Praha

White, B.W., 1988: Geomorphology and Hydrology of Karst Terrains, Oxford Unifersity Press, p. $1-464$

Zapletal, J., 1989: Podtratová jeskyně -vertikální rozpětí přes $100 \mathrm{~m}$. Zpráva o průzkumné činnosti za období 1981-1989. - Český kras, 15, p. 81-85, Beroun

Žák, K. \& J. Hladíková \& R. Kadlecová \& V. Ložek \& V. Cílek \& J. Kadlec \& A. Žigová \& J. Bruthans \& M. Štastný, 2001: Holocenní vápence a krasový pramen ve Svatém Janu pod Skalou v Českém krasu. - Čes. geol. Úst., Praha 